\title{
Time of guard of orthodontic records versus legal time for their prescription
}

\author{
Luiz Renato Paranhos¹, Mariana Paula Maggiorini de Magalhães², José Francio³, Hélio Hissashi Terada4, \\ Henrique Damian Rosário ${ }^{5}$, Rhonan Ferreira da Silva ${ }^{6}$
}

Introduction: After promulgation and wider dissemination of the Code of Consumer Protection, there was an increase in the number of legal conflicts between patients and dentists, leading these health professionals to increasingly guard themselves from possible lawsuits. As such, it becomes critical the preparation of an adequate and complete clinical record, even though the keeping time remains uncertain. Objective: To review the literature and discuss the keeping time of orthodontic records versus the legal time for their prescription, as well as to propose a model of a Term upon Completion of Dental Treatment. Conclusion: It is advised to return part of the clinical records to their rightful owners by means of an itemized receipt. The Term upon Completion reflects the patient's awareness and could be considered by the CCP as the initial term of the prescription time, because it implicates that the patient recognizes the quality of service provided and satisfactory results achieved.

Keywords: Documentation. Orthodontics. Forensic dentistry. Legislation.

Introdução: após a promulgação e maior divulgação do Código de Defesa do Consumidor (CDC), aumentou o número de conflitos legais entre pacientes e cirurgiões-dentistas, fazendo com que o profissional da saúde passasse a se resguardar cada vez mais quanto ao risco de eventuais processos. Para sua defesa, é indispensável a elaboração de um prontuário clínico adequado e completo, porém, o tempo que esse deve ser guardado é uma incógnita. Objetivo: o objetivo do presente estudo é rever a literatura e discutir sobre o tempo de guarda da documentação ortodôntica versus o prazo de prescrição legal, além de propor um modelo de termo de conclusão de serviços odontológicos. Conclusão: aconselha-se a devolução de parte dos documentos clínicos ao seu legítimo dono mediante recibo discriminado. O "Termo de Conclusão" traduz o conhecimento da conclusão do tratamento pelo paciente e poderia ser considerado termo inicial do prazo prescricional pelo CDC porque nesse consta que o paciente reconhece a qualidade do serviço e o resultado satisfatório.

Palavras-chave: Documentação. Ortodontia. Odontologia Legal. Legislação.

${ }^{1}$ Post-Doc in Forensic Dentistry and Deontology, FOP/UNICAMP. Professor, Department of Oral Biology, Sacred Heart University (USC), Bauru, SP, Brazil. ${ }^{2}$ Student of the Specialization Course in Orthodontics, Idée Dentistry/Uningá. ${ }^{3} \mathrm{MSc}$ in Forensic Science, UNIVALE. Magistrate Professor, Law School, UNOESC, Joaçaba, SC, Brazil.

${ }^{4} \mathrm{PhD}$ in Orthodontics, UNESP. Professor, Department of Orthodontics, School of Dentistry, State University of Maringá, Maringá, PR, Brazil. ${ }^{5} \mathrm{PhD}$ Student in Oral Biology, Sacred Heart University (USC), Bauru, SP, Brazil. ${ }^{6} \mathrm{PhD}$ in Oral-Dental Biology, UNICAMP. Professor, Department of Forensic Dentistry, School of Dentistry, Federal University of Goiás and Paulista University, Goiânia, GO, Brazil.

\footnotetext{
How to cite this article: Paranhos LR, Magalhães MPM, Francio J, Terada HH, Rosário HD, Silva RF. Time of guard of orthodontic records versus legal time for their prescription. Dental Press J Orthod. 2013 May-June;18(3):113-7.

Submitted: December 05, 2012 - Revised and accepted: February 26, 2013

» The authors report no commercial, proprietary or financial interest in the products or companies described in this article.

Contact address: Luiz Renato Paranhos

Email: paranhos@ortodontista.com.br
} 


\section{INTRODUCTION}

The increased dissemination of the Code of Consumer Protection $^{1}$ (CCP) and the absence of a specific legislation for the provision of dental services have broadened the number of legal conflicts between patients and dental surgeons (DS). As a way for professionals to ensure themselves from possible lawsuits, the preparation of an adequate clinical record becomes indispensable, even though its keeping time remains doubtful for dental professionals, service providers and intermediating providers of dental services.

The Brazilian Code of Civil Procedure states in the Chapter VI (Of Evidence), in which is inferred that the record is a document of probative force to defend the dental surgeon (DS), as disposed in the article 332, that: "All legal as well as morally legitimate means, though not specified in this Code, are able to prove the truth of the facts on which are based the claim or defense". ${ }^{2}$ In addition to this legal issue, the development and updated maintenance of dental records in a separate file are ethical professional duties according to the Dental Code of Ethics, ${ }^{3}$ and the elements contained therein may be requested for purposes of human identification. ${ }^{4,5,6}$

The scientific literature has no consensus on the need and keeping time of dental records, and there are even those who say that this period should be unlimited. ${ }^{7}$ The Statute of Children and Adolescents $^{8}$ (SCA) clearly requires hospitals and other health care facilities supporting pregnant women (either public or private) to keep records (individual forms) of activities for eighteen years - until reaching the age of majority.

Keeping clinical documentation (or also called the clinical record, e.g. clinical and anamnesis forms, treatment plan, informed consent, contract of service delivery, imaging tests - X-rays, CT scans, photographs etc, dental certificate, referrals, plaster casts, and all types of documents produced as a result of the care given to the patient) has been being questioned and discussed in the field of forensic dentistry. It was suggested that the best thing to do is to deliver part of this documentation to its rightful owner, ${ }^{9}$ or even give it 5 years after the end of the orthodontic treatment, ${ }^{5}$ in both cases by means of an itemized receipt of all documents provided.
It is pointed out the advantage in keeping only the receipt paper, which would take much less space; and regarding the burden of proof, the DS should only present the receipt that the responsibility for putting such documents under court, if necessary, would turn to the patient. Also, it is worth noting that the patients, in bad faith, may hide such records from the court. They will do so when records contain evidence unfavorable to their legal claim. One can argue, for example, that had the documents lost or misplaced. In this case, the absence of such documents, by itself, will not cause the patient major consequences. However, the patient must prove his/her allegations by other evidences. With regard to the professional, the instrument of defense or proof of his/her reasons will remain to be the clinical record in the form of a descriptive report.

Therefore, the clinical record composed by anamnesis, dental chart, clinical treatment outcomes - report of the diverse occurrences, procedures, measures and recommendations given to the patient etc - may be filed both in binder and computerized system, since it has digital signature of the patient or caregiver to give validity to the data. ${ }^{10}$ For legal purposes, it is important for the professional to keep the clinical record at hand, i.e., the report of occurrences that happened during the treatment. In this case, the fuller is the report, the more ensured will be the professional in proving his/her conduct and how clinical condition evolved in the course of treatment.

In other words, the literature showed that many of the procedures performed in the dental practice can present with faults barely identifiable (hidden defect), implying the maintenance of the patient's records in full indefinitely. ${ }^{11}$

The awareness of the prescription of an action represents the end of the proceedings with judgment on merits, in the terms of the article 269, Paragraph IV of the Code of Civil Procedure, ${ }^{2}$ which states: "Article 269. There will be resolution of the merits: $I V$ - when the judge declares decline or prescription". This means that the action was stillborn. That is, after a given time any legal action with indemnity purposes has no legal support. Nevertheless, it is worth noting that such circumstance by itself does not exempt the professional from the obligation of replying the proceedings with the help 
of a counselor. This happens because although the prescription is matter of public law that can be recognized ex officio by the judge, the counselor is required to contest the lawsuit, pointing out not only the prescription, but also the merits, i.e., besides claiming the prescription, the counselor should develop a complete defense relevant to the case. Why must this be so? Because in the case the judge does not admit the prescription, the absence of contestation as to the merits may lead the defendant the consequences of default, which is the presumption of truth regarding the facts alleged by the author. In this respect, the article 319 of the Code of Civil Procedure ${ }^{2}$ states: "If the defendant does not contest the action, the facts stated by the author will be deemed true".

The recognition of the prescription time for civil lawsuits may depend on the use of evidences and the object of the contractual relationship, noting that the article $206, \sqrt{ } 3^{\text {rd }}$, incise $\mathrm{V}$ of the current Brazilian Civil Code (Law no. 10.406/2002) ${ }^{12}$ in force since $01 / 11 / 2003$, reduced the prescription time to three years.

However, with the previous approval of the Code of Consumer Protection $^{1}$ (Law 8.078/1990), the relationship patient-health professional was considered as a consumption relationship, due to the contained in the article $2^{\text {nd }}$, which defines as a consumer "any person or entity that acquires or uses products or services as final receiver". It is understood, therefore, by this law, that any person or entity engaged in economic activity, even atypical or occasional, characterizes a consumption relationship. As such, the medical professional or dentist is the service provider and the patient is the consumer. Generally, the service may be the medical or dental act such as the consultation, intervention or other procedure.

Moreover, the $\mathrm{CCP}^{1}$ is the law that preserves the public order targeting the social interest. Therefore, since it is in force, it has been applicable to all issues dealing with consumption relationship. So the prescription of the action claiming damage repair due to medical or dental misconduct shall be governed by the article 27 of this law, which states: "Article 27. It is prescribed in five years the pretension to the repair of damages related to the product or service provided, according to the Section II of this chapter, counting the time from the awareness of the damage and its authorship".
In this sense, it is appropriate to refer to a recent decision of the Superior Court of Justice issued on Motion for Clarification of Special Appeal, which thus established: "The jurisprudential orientation of this Superior Court is that the Code of Consumer Protection is applied to medical services, including those related to the five-year limitation period advocated in the article 27 of the CCP". ${ }^{13}$

\section{DISCUSSION}

Many doubts may be raised as regards the prescriptional time. So, it is questioned if the consumption relationship should be ruled by the Civil Code ${ }^{12}$ (article $206, \int 3^{\text {rd }}$, incise V) that establishes three years, or by the Code of Consume Protection (article 27) that determines five years. The solution deemed as legally feasible lies on the fact that the entry into force of the new Civil Code ${ }^{12}$ did not change the estimation set out in the Code of Consumer Protection. This is because the latter is a specific law that must prevail over the law that has general character. This prescription time also prevails when the responsible for the damage is a public entity such as a hospital or clinics held by the government.

Since when does the counting to the prescription time start? The counting starts from the moment that the damage is identified, i.e., when the patient or his/ her legal guardian becomes aware of the fact. Obviously, in the case of dental services, the legal relationship between the service provider and the consumer becomes unstable and insecure, because this time has become somewhat subjective, and is always dependent on a future and uncertain issue. In other words, when will the patients come to know the fact that caused them harms? This is not known, nor predictable. Nonetheless, one should remember that the majority of jurisprudence states that the time of prescription is five years. Here, it is recommended whenever possible to have the patient's written consent, including his/her signature on the sidelines of the dental chart, for example, or on another document.

In view of this legal uncertainty, it is difficult to know how long health professionals should keep the care records under their custody.

Hence, one should follow here the unwritten rule of common sense, which recommends that each one should endeavor in order to be the safest possible. It is better to keep the records for a longer time. "Man forewarned is forearmed". 
This caution is justified still by the fact that it is not enough for the professionals to be assured they did everything right or think that the patient seems well-intentioned. One cannot ignore that there are indemnity actions proposed in bad faith, in expectation of easy money, a kind of lottery game. This occurs especially when the author has legal aid - does not pay costs or honorariums and is not subjected to the burden of defeat. So, there would be nothing to lose. It could still be inferred that the author, in such cases, should be condemned as a litigator in bad faith, based on the article 16 of the Code of Civil Procedure, ${ }^{2}$ which says: "Responds for damages and losses that individual who claims in bad faith as an author, defendant or intervener". Nonetheless, this condemnation will have little effect if the author has no proven financial conditions to reimburse the damages.

Finally, there is another ethical and moral issue in keeping patient's records longer: The occasional need for identification in case of accident or criminal event - that requires the help of human identification tools. Thus, it is concluded that guard of orthodontic records must be taken seriously by the dentist and, again, decided reasonably according to the real needs of each case.

\section{PROPOSAL FOR A TERM UPON COMPLETION OF DENTAL TREATMENT}

The possibility of delivering the clinical record by means of a receipt to the patient or caregiver is legal and feasible, since the dentist keeps the patient's dental records either in signed paper or digital media, including anamnesis, initial and final dental chart, clinical evolution, considerations and drug prescriptions, copies of certificates, prescriptions and referrals, as well as duplicate of the contract for dental services and informed consent term. Documents and exams requested by the patient, such as radiographs (with tracing), photographs and plaster casts (due to the volume these occupy), can be delivered to the interested legitimate person - by signing the receipt and not to a third party.

The provision of services between the DS and the patient leads a business or legal pact. In order to guaran-

\section{TERM UPON COMPLETION OF DENTAL TREATMENT}

Professional's:

Patient's:

Patient's Legal Guardian:

By this term upon completion of services, the parties are in agreement that:

a) The services proposed in the contract as of ______/_- were accomplished b) There were improvements both in esthetical and functional features, with specific recovery of the following aspects:

c) The patient declares to be in agreement and satisfied with the final result achieved in the treatment, recognizing expressly that it met his/her expectations. d) The professional affirms that received the amount of money foreseen in the contract. Or: It is established that the balance due shall be paid as follows:

e) The patient declares receiving, in this act, the following materials and docu ments, which will bekeptunderhis/hercustody and exclusiveresponsibility:

In view of the aforementioned facts, accepted by the parties as an expression of truth, sign this document for legal purposes.

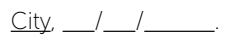

Professional's signature:

Patient's

Name:

Figure 1 - Term upon completion of treatment to be used at the end of the orthodontic treatment. Note the presence of receipt of records on the part of the patient or legal guardian.

tee the management of this relationship, it is absolutely recommended that the DS be ensured by a contract of service delivery so doubts or difficulties will not come to foster future discussion. This same caution can be adopted with the signing of a term upon completion of treatment, according to a model proposed herein (Fig 1). This term reflects the awareness of the fact by the patient and could be considered as the initial term of the prescription time by the CCP, because it implies that the patient recognizes the quality of service provided and satisfactory results achieved. 


\section{REFERENCES}

1. Brasil. Lei ordinária n. 8.078 de 11 de setembro de 1990. Dispõe sobre a proteção do consumidor e dá outras providências. Diário Oficial da União, 1990 set 12, suplemento.

2. Brasil. Lei ordinária n. 5.869 de 11 de janeiro de 1973. Institui o Código de Processo Civil. Diário Oficial da União, 1973 jan 17. Art. 269 Haverá resolução do mérito: IV quando o juiz pronunciar a decadência ou a prescrição.

3. Brasil, Conselho Federal de Odontologia Resolução 118/2012, de 11 de maio de 2012: Revoga o Código de Ética Odontológica aprovado pela Resolução CFO-42/2003 e aprova outro em substituição. Disponivel em http://www.cfo.org.br

4. Silva RF, Ramos DIA, Pereira SDR, Daruge E, Daruge-Júnior E. Modelos de gesso: importância pericial e orientações odontolegais para arquivamento. Rev Assoc Paul Cir Dent. 2007;61(5):381-4

5. Paranhos LR, Salazar M, Torres FC, Pereira AC, Silva RF, Ramos AL. Profile evaluation of orthodontics professionals as for their legal actions. Dental Press J Orthod. 2011:16(5):127-34.

6. Silva RF, Chaves P, Paranhos LR, Lenza MA, Daruge-Júnior E. Use of orthodontic records in human identification. Dental Press J Orthod. 2011;16(2):52-7.
7. Vanrell JP. A documentação odontológica. In: Odontologia legal e antropologia forense. Rio de Janeiro: Guanabara Koogan; 2009. p. 193-8

8. Brasil. Lei ordinária n. 8.069 de 13 de julho de 1990. Dispõe sobre o Estatuto da Criança e do Adolescente e dá outras providências. Diário Oficial da União, 1990 jul 16

9. França BHS. Documentação clínica do paciente: guardar por quê? Rev Clín Ortod Dental Press. 2007:6(5):48-9

10. Cerveira JGV. A legalidade dos documentos digitais. Odontologia Clín Científ. 2008:7(4):299-302.

11. Vassão SAS, Carvalho RB, Medeiros UV, Santos KT. Prevenção a riscos jurídicos no exercício da odontologia: o que o cirurgião-dentista deve saber. Rev Assoc Paul Cir Dent. 2009;63(5):390-94.

12. Brasil. Lei Ordinária n. 10.406 de 10 de janeiro de 2002. Dispõe sobre o novo Código Civil. Diário Oficial da União, 2002 jan 11

13. Brasil. Supremo Tribunal de Justiça. Recurso Especial (2012). EDcl no REsp 704.272/SP, Rel. Ministra Maria Isabel Gallotti. Quarta Turma, julgado em 02/08/2012, DJe 15/08/2012. 